\title{
USING RELATEd LEgAL SyStemS TO SECURE THE EXECUTION OF JUST SATISFACTION AWARDED BY THE ECTHR
}

\section{Accepted \\ 20. 9. 2021 \\ Revised \\ 25. 11. 2021 \\ Published \\ 22. 12. 2021}

Keywords

ECHR,

enforcement,

execution,

$\mathrm{EU}$

law,

immunity,

human

rights
ACHILLEAS DEMETRIADES \&

Alexandros Demetriades

Lellos P. Demetriades Law Office LLC, Nicosia, Cyprus.

E-mail: achilleas@ldlaw.com.cy, alex@ldlaw.com.cy

CORRESPONDING AUTHOR

achilleas@ldlaw.com.cy

Abstract The present article hopes to initiate a discussion concerning alternative methods through which applicants themselves can ensure that recalcitrant respondent States comply with their obligations to execute the judgments of the ECtHR. This may be done by mobilising related legal systems towards this end. This paper focuses on the 'just satisfaction' element of the judgment and examines one possible avenue through which applicants themselves can secure their payment. The relevant course of action has two elements: (i) securing the recognition of the ECtHR's order to pay within the national legal order of a non-respondent High Contracting Party to the Convention and requesting that the relevant national court issue a third-party debt order against the European Commission and (ii) securing the waiver of the European Commission's immunity. 


\section{$1 \quad$ Introduction}

A judgment of the European Court of Human Rights (hereinafter: ECtHR or the Court) which finds that a European Convention on Human Rights (hereinafter: ECHR or the Convention) ${ }^{1}$ right has been violated creates a three-fold secondary obligation incumbent on the respondent State to: ${ }^{2}$ (i) pay just satisfaction to the applicant (see Article $41 \mathrm{ECHR}$ ); (ii) implement individual measures with a view to achieving restitutio in integrum ${ }^{3}$ and (iii) implement general measures. This obligation binds the respondent State by virtue of Article 46(1) ECHR. The execution of this obligation is supervised by the Committee of Ministers (hereinafter: CoM) (Article 46(2) ECHR).

The ECtHR has been lauded for being 'as effective as ... any domestic court' in terms of the compliance rate by respondent parties (Helfer, Slaughter, 1997: p. 296). This appears to be overstated. Currently, 5,233 judgments are still pending execution before the CoM (Committee of Ministers 2020: p. 43). Two main problems plague the current system of executing ECtHR judgments. First, the incomplete execution of judgments indicates that the protection afforded under the ECHR may be rendered ineffective when faced with a recalcitrant State ${ }^{4}$ This undermines the credibility of the Convention regime (Council of Europe 2004: para. 16). Secondly, the heavy caseload of the CoM has caused an administrative strain. This leads to less intensive supervision, which contributes to the delays in executing the judgments of the Court (CCBE 2019: para. 5). ${ }^{5}$ This paper proposes an alternative avenue to ensure the execution of ECtHR judgments using national legal orders and other related legal institutions, such as the EU legal framework.

This study is limited in two respects. Primarily, the proposed claim is limited to ensuring the execution of the just satisfaction element of the ECtHR judgment (Article 41 ECHR), which appears to have become the 'go-to remedy' for the ECtHR (Fikfak, 2018: p. 1095). The importance of ensuring the execution of just

\footnotetext{
${ }^{1}$ Convention for the Protection of Human Rights and Fundamental Freedoms (entered into force 3 September 1953) 213 UNTS 221.

${ }^{2}$ ECtHR 13 July 2000, Case No. 39221/98 and 41963/98 Scozzari and Giunta v Italy, para. 249.

${ }^{3}$ ECtHR 31 October 1995, Case No. 14556/89 Papamichalopoulos v Greece (Article 50), para. 34.

${ }^{4}$ E.g. Interim Resolution CM/ResDH(2014)185 'Execution of the judgments of the European Court of Human Rights in the cases Varnava, Xenides-Arestis and 32 other cases against Turkey' (25 September 2014).

${ }^{5}$ Currently, it could take up to 15 years after the initial application to the ECtHR for full redress of the violation to be achieved.
} 
satisfaction should not be underestimated. There were instances in which the failure to execute the monetary aspect of a judgment has contributed to both problems identified above. Respondent States have refused to pay when the sum awarded was particularly large ${ }^{6}$ or in politically sensitive cases, such as the Xenides-Aresti line of cases, concerning Turkey's violations of Article 1 Protocol 1 ECHR 7 in the occupied territory of Northern Cyprus. ${ }^{8}$ This selective compliance illustrates the regime's ineffectiveness, especially when considering the unambiguous nature of the obligation to pay. Furthermore, $26 \%$ of just satisfaction awards are paid belatedly (Glas, 2017: p. 47) (Committee of Ministers 2020: p. 64). This creates a backlog for the CoM, hindering its operations (Lambert-Abdelgawad, 2008: p. 35).

The second limitation is that the paper does not conduct an exhaustive survey of possible ways in which national law may be utilised to ensure the execution of the ECtHR's judgments but examines one potential claim in depth, leaving it to others to devise their own course of action within their respective national systems.

Within these parameters, this paper hopes to answer the following question: How can we utilise the existing legal framework - as well as related legal orders and institutions - to ensure that the just satisfaction awarded by the ECtHR is paid?

In answering this question, the study first considers the causes underpinning the problems of ineffectiveness and delays. To address these problems, it is argued that a more robust mechanism of legal coercion is required at the post-judgment stage. This could be provided through the use of related legal institutions, such as national courts, in order to compel the execution of the monetary aspect of ECtHR judgments.

This paper will then examine one plausible claim through which the applicantturned-judgment-creditor may use the ECtHR judgment to compel the payment of just satisfaction. The proposed claim involves issuing a garnishee order (i.e. a third party debt order) in favour of the applicant in order to collect the award from the

\footnotetext{
${ }^{6}$ Decision CM/Del/Dec (2019) 1340/H46-20 'H46-20 Oao Neftyanaya Kompaniya Yukos v. Russian Federation (Application No. 14902/04)' (14 March 2019).

${ }^{7}$ Article 1 Protocol 1 ECHR: 'Every natural or legal person is entitled to the peaceful enjoyment of his possessions. No one shall be deprived of his possessions except in the public interest and subject to the conditions provided for by law and by the general principles of international law. ...'

${ }^{8}$ Interim Resolution CM/ResDH (2014) 185 (n. 4).
} 
funds owed to the respondent State by the EU institutions. The reason for focusing on this claim is that at least one such case has already come before the Court of Justice of the European Union (hereinafter: CJEU). ${ }^{9}$

The proposed course of action has three phases. First, the award of just satisfaction made by the ECtHR judgment must be recognised by the national court of the forum State. ${ }^{10}$ It is argued that it is plausible for an order made by the ECtHR to be recognised within the national legal order of some Contracting Parties, even if those Parties are not the addressees of the judgment. This recognition would enable the national court to issue a garnishee order nisi against an EU institution ${ }^{11}$ in order to secure the payment of just satisfaction owed to the applicant. The second stage of garnishee proceedings involves the waiver of the EU institution's immunity under Article 1 Protocol (No. 7) on the Privileges and Immunities of the EU, annexed to the TEU, the TFEU and the EAEC Treaty (hereinafter: Protocol No. 7 TEU). ${ }^{12}$ The paper examines the prospects of this immunity being waived to allow the applicant to collect the sum from the garnishee (in this case, the European Commission). Finally, the case is returned to the national court in order to affirm its initial decision and issue a garnishee order absolute. It is acknowledged that this claim is not necessarily a panacea. However, this article hopes to initiate a discussion regarding the ways in which national and other related legal systems can assist in the execution of the judgments of the ECtHR.

\section{A Proposal for a New Direction}

\subsection{Reliance on Political Pressure}

The key problems facing the ECHR regime were stated above. It is argued that the issues identified arise because the mechanisms in place to supervise the Member States executing ECtHR judgments are based on political pressure and lack legal coercive force (Glas, 2017: p. 108).

\footnotetext{
${ }^{9}$ Case C-675/19 SA, Dinos Ramon v Commission, ECLI:EU:C:2020:683 (hereinafter: Ramon (CJEU)).

${ }^{10}$ The forum State is the jurisdiction whose national court will recognise the ECtHR judgment and seek to enforce it through issuing the third party debt order (i.e. garnishee order).

${ }^{11}$ The reason that the third party debt order is made against an EU institution is that many such institutions finance States which are Contracting Parties to the ECHR and which may have not paid just satisfaction owed to applicants before the ECtHR / judgment creditors.

${ }^{12}$ [2012] OJ C326/266.
} 
The mechanisms used to supervise the execution of judgments revolve around the exertion of political pressure on the respondent State to comply with its secondary obligations. It is argued that such political pressure is not necessarily effective in ensuring that human rights standards are observed (Hafner-Burton, 2008: p. 713).

If the respondent State fails to comply, the CoM has traditionally had two mechanisms through which it could censure the recalcitrant State. Primarily, it may adopt an interim resolution reprimanding the State. ${ }^{13}$ Alternatively, the CoM may invoke Article 8 of the Statute of the Council of Europe ${ }^{14}$ in order to suspend the violating State's rights of representation or to expel it from the Council altogether. While the former measure is ineffective, the latter is largely theoretical and has never been used to punish the non-execution of an ECtHR judgment (LambertAbdelgawad 2008: p. 41).

Protocol No. 14 ECHR $^{15}$ created an additional tool in the form of infringement proceedings under Article 46(4) ECHR. According to this procedure, when a State refuses to execute the initial judgment of the ECtHR, the CoM may, with the support of two-thirds of its members, refer the case back to the Court. The ECtHR will determine whether the respondent State has discharged its obligation under Article 46(1) ECHR. If not, the case is referred back to the CoM, which will continue to supervise its execution. Thus, while giving the appearance of legal accountability, this procedure merely adds an extra step to the traditional method of ensuring the execution of judgments through political pressure.

The procedure was used for the first time in the case of Ilgar Mammadov $v$ Azerbaijan (Article 46(4) ECHR), ${ }^{16}$ which concerned the pre-trial imprisonment of a prominent critic of the Azerbaijani government. In the initial proceedings before it, the ECtHR held that Azerbaijan had violated Articles 5, 6 and 18 ECHR. ${ }^{17}$ Following that judgment, Azerbaijan failed to implement the individual measures required. ${ }^{18}$ Upon referral, the ECtHR concluded that Azerbaijan had breached its obligations under

\footnotetext{
${ }^{13}$ E.g. Interim Resolution CM/ResDH(2014)185 (n.4).

14 (entered into force 3 August 1949) ETS No. 001.

15 (entered into force 1 June 2010) CETS No. 194.

${ }^{16}$ ECtHR 29 May 2019, Case No. 15172/13 Ilgar Mammadov v Azerbaijan (Article 46(4) ECHR).

${ }^{17}$ ECtHR 22 May 2014, Case No. 15172/13 Ilgar Mammadov v Azrerbaijan.

${ }^{18}$ Ilgar Mammadov (Article 46(4) ECHR) (n.17), para. 175.
} 
Article 46(1) ECHR and referred the case back to the CoM. ${ }^{19}$ This test case appears to do little more than affirm the obvious fact that Azerbaijan had not complied with its obligations under Article 46(1) ECHR. The ECtHR did not impose any penalty on the recalcitrant State. Instead, the Court recognised that the infringement proceedings rely on political pressure to induce execution. ${ }^{20}$ The Mammadov saga appears to confirm the view that the Article 46(4) procedure is largely futile and that it is unlikely to effectively address the problem of non-execution (De Londras and Dzehtsiarou 2017: pp. 484-486). ${ }^{21}$

\subsection{A New Direction: Using Legal Mechanisms to ensure Execution}

The difficulties faced by the CoM have driven the ECtHR to take a more proactive role in the execution of its own judgments by indicating specific measures which may be taken by the respondent State to comply with its obligations. This guidance aids the CoM in fulfilling its role (Keller and Marti, 2016: p. 839). The Court's involvement adds a much-needed legal dimension to the execution, supplementing political mechanisms in place.

In principle, the judgments of the ECtHR are 'declaratory', allowing the State to decide how it should discharge its secondary obligations under the judgment. ${ }^{22}$ Although this has been reaffirmed, ${ }^{23}$ the Court has recently taken a more directive approach in some judgments (Paraskeva 2018: pp. 55-56) by proposing specific measures. ${ }^{24}$

Despite the increased judicialisation of execution at the judgment phase, the involvement of the ECtHR in the post-judgment stage of proceedings (i.e. the supervision of execution) is more restrained (Keller and Marti, 2016: p. 845). In this respect, the ECtHR defers towards the institutional balance struck by the Convention. ${ }^{25}$ The ECtHR exerts some influence over the execution of judgments.

\footnotetext{
${ }^{19}$ Ibid, para. 218.

${ }^{20}$ Ibid, para. 159.

${ }^{21}$ After the CoM initiated proceedings under Article 46(4) ECHR, Mr. Mammadov was released. However, this was not taken into account by the ECtHR in issuing its judgment pursuant to Article 46(4) ECHR. Therefore, it is assumed that the tenor of the judgment would have been similar even if the applicant had not been released. Ilgar Mammadov (Article 46(4) ECHR) (n.17), paras. 205-208.

22 ECtHR 13 June 1979, Case No. 6833/74 Marckx v Belgium, para. 58.

${ }^{23}$ ECtHR 8 April 2004, Case No. 71503/01 Assanidze v Georgia, para. 202.

24 See for example ECtHR 9 January 2013, Case No.21722/11 Oleksandr Volkov v Ukraine, para. 195.

${ }^{25}$ ECtHR 12 March 2014, Case No. 26828/06 Kuric and Others v Slovenia (Just Satisfaction), para. 142.
} 
One such example can be found under the Article 46(4) procedure outlined above. Alternatively, determining just satisfaction at a different time to the merits of a claim allows the Court to consider whether the judgment has been complied with. ${ }^{26}$ While the efforts to involve the Court in the execution of its own judgments are commendable, it is argued that they are insufficient. The current system of political pressure should be supplemented with a robust mechanism ensuring legal accountability (Keller and Marti, 2016: p. 850). Absent reform, the ECtHR cannot adequately fulfil the role of legal enforcer in the post-judgment phase. Therefore, one should look to related legal systems to find institutions that can fulfil this role. It is argued that the national courts of Contracting Parties could assume the responsibility of supplementing the political system of execution with coercive legal mechanisms in order to secure the payment of compensation for human rights violations. This possibility has already been recognised by commentators (Nollkaemper, 2013: p. 531). The following section considers one way to realise this proposition.

\section{$3 \quad$ Using related Legal Orders: The 'Ramon Claim'}

The following section examines one way to mobilise national legal systems in order to ensure that rogue respondent States are compelled to pay the just satisfaction awarded by the ECtHR. This can be done by obtaining a garnishee order (i.e. a thirdparty debt order) against one of the debtors of the respondent State (the judgment debtor). The paper chooses to focus on garnishee proceedings against the EU Commission. ${ }^{27}$ This is particularly pertinent because at least one case has attempted to use this method to execute a judgment issued by the ECtHR in the form of Dinos Ramon $v$ Turkey and EU Commission (hereinafter: Ramon (national judgment) ${ }^{28}$ and Dinos Ramon v Commission (hereinafter: Ramon (CJEU). ${ }^{29}$

There are two elements of proceedings to execute a judgment through the garnishee order successfully. Primarily, the monetary award made by the ECtHR must be recognised and enforced by the relevant national court, which would serve as the forum for the garnishee proceedings. It is this national court that will issue the

\footnotetext{
${ }^{26}$ Ibid, para. 138.

${ }^{27}$ Protocol (No. 7) TEU (n.12).

${ }^{28}$ Famagusta District Court judgment of 26 June 2019 Dinos Ramon v Turkey and EU Commission General App. 8/2019 (Ramon (national judgment)).

${ }^{29}$ Case C-675/19 SA Dinos Ramon v Commission, ECLI:EU:C:2020:683.
} 
garnishee order. Secondly, if the national court issues the order, one should consider whether the immunity enjoyed by the EU Commission will be waived. These elements will be examined in turn.

\subsection{Transposing the ECtHR judgment into the national legal order}

A final judgment of the ECtHR has two elements: (i) precedential value in interpreting the relevant provision of the Convention and (ii) operative parts which collectively constitute res judicata (Polakiewicz, 2002: p. 72).

\subsubsection{Precedent in the national legal order}

An ECtHR judgment has precedential value regarding the construction of the relevant Convention right. ${ }^{30}$ Strictly speaking, there is no obligation incumbent on the Contracting Parties to make the ECHR or the judgments of the ECtHR directly effective. Hence, whether a judgment of the Court will be self-executing within the domestic legal order will depend on the relevant national law (Ress, 2005: p. 374).

The ECtHR has suggested that if the precedent generated by the judgment is precise and complete, it should be directly effective, at least with respect to the national legal order of the respondent State. ${ }^{31}$ Significant State practice appears to endorse and expand this proposition. Precedents set by the ECtHR have, without further formalities, been adopted by national courts in the Member States that are not the addressees of the precedent-setting judgments (see, for example, s.2(1) Human Rights Act 1998 (UK); De Wet, 2008: pp. 243-245). ${ }^{32}$ Some commentators consider that precedent forms part of the relevant provision and is, therefore, binding erga omnes (on all Contracting Parties) through the Convention (Polakiewicz, 2017). Therefore, it is argued that, in practice, precedents set by the ECtHR have a quasidirect effect in the national legal orders of many non-respondent Contracting Parties (Martinico, 2012: pp. 417-418).

\footnotetext{
${ }^{30}$ ECtHR 24 November 2005, Case No.49429/99, Capital Bank. AD v Bulgaria, para. 79.

${ }^{31}$ ECtHR 29 November 1991, Case No. 12849/87 Vermeire v Belgium, paras. 25-26.

32 See also R(Ullah) v Special Adjudicator [2004] UKHL 26, para. 20.
} 


\subsubsection{Res Judicata in the national legal order}

The second element is what may be collectively termed 'res judicata'. ${ }^{33}$ This covers determinations and orders made by the ECtHR in the operative part of the judgment, including just satisfaction. It is this res judicata aspect that must be transposed into national law so that the national court can serve as a forum to execute the ECtHR judgment. In determining the effect of res judicata on the domestic legal system, a distinction should be drawn between: (i) judgments addressed to the forum State and (ii) judgments not addressed to the forum State.

\subsubsection{Res Judicata in the national legal order of the Respondent}

The res judicata element of a judgment is binding on the respondent State by virtue of Article 46(1) ECHR. This imposes an obligation on all national authorities of the respondent State, including national courts, to make reparations regarding relevant violations (Polakiewicz, 2002: p. 66).

Given the obligations incumbent upon the respondent, the applicant could initiate a claim in the national courts of the respondent State. The national court would be under obligation to recognise the order made by the ECtHR and to provide a cause of action to the applicant, which would effectively redress the violation committed by the State.

It is argued that an action in the national court of the respondent with the object of executing an ECtHR judgment is unlikely to achieve the applicant's objective in practice. Primarily, the national court could refuse to comply with the ECtHR judgment, despite its obligations under Article 46(1) ECHR. One such example is the Russian Constitutional Court's refusal to execute the award of $€ 1,866,104,634$ ordered by the ECtHR in OAO Neftyanaya Kompaniya Yukos v Russia Just Satisfaction). ${ }^{34}$ The Russian Constitutional Court held that it was not bound by the ECtHR judgment on the grounds that the ECtHR's interpretation of Article 1

\footnotetext{
33 This should not be confused with the doctrine which bars relitigation of a claim that has already been adjudicated upon, which is a different understanding of the term res judicata.

${ }^{34}$ ECtHR 31 July 2014, Case No. 14902/04.
} 
Protocol 1 ECHR came into conflict with the normatively superior Russian Constitution. ${ }^{35}$

Furthermore, if the refusal to execute a judgment is due to a deterioration of democratic governance in the respondent State, it is possible that the national judiciary could be co-opted in this authoritarian turn. This could mean that national courts will refuse to execute judgments against the State. An example can be found in Turkey, which has seen an increase in human rights repression in recent years (Dalhuisen, 2017). The Turkish Constitutional Court (hereinafter: TCC) has refrained from challenging governmental actions taken pursuant to emergency decrees (Observatoire International des Avocats, 2018: p. 8). Even when the TCC has taken action to protect human rights, lower courts in Turkey have refused to implement its orders. ${ }^{36}$ The ECtHR has indicated that this raises 'serious doubts' about the effectiveness of certain judicial remedies afforded by Turkish law. ${ }^{37}$

Given that national courts of the respondent State are likely to be an inhospitable forum for the applicant's claim to execute the ECtHR judgment, alternative forums must be found. It is argued that national courts of other Contracting Parties could play a role in executing the just satisfaction element of an ECtHR judgment, even though that judgment is not directly binding on the forum State (CCBE, 2019: para.36(c)).

\subsubsection{Res Judicata in the national legal order of non-respondent Contracting Parties}

There has been little to no examination of the legal significance of res judicata arising from a Strasbourg judgment in the national legal order of a non-respondent Contracting Party. There appears to be no equivalent to Article 46(1) ECHR that would bind national courts of non-respondent Member States to recognise the orders made by the ECtHR.

Nevertheless, there is at least one jurisdiction in which the national court has recognised the res judicata emanating from a Strasbourg judgment against another

\footnotetext{
${ }^{35}$ Russian Constitutional Court Judgment of 19 January 2017 No. 1-П/2017

<http://www.kstf.ru/en/Decision/Judgments/Documents/2017_January_19_1-P.pdf> accessed 20 July 2019, pp. 5-10.

${ }^{36}$ ECtHR 20 March 2018, Case No. 13237/17 Mehmet Hasan Altan v Turkey, para. 134.

${ }^{37} \mathrm{Ibid}$, para. 142.
} 
Contracting Party within its own domestic legal order. This occurred in Ramon (national judgment). The applicant in this case was a Greek-Cypriot owner of a clinic located in the Famagusta district, in the northern part of Cyprus. Following the Turkish invasion in 1974, Dr Ramon was forced to flee the area. The district remains under the 'effective control' of Turkey. ${ }^{38}$ This has prevented the applicant from making use of his property. The applicant brought a claim before the ECtHR, which held that Turkey had violated Dr. Ramon's rights under Article 1 Protocol 1 ECHR. ${ }^{39}$ The ECtHR awarded just satisfaction amounting to $€ 458,000,{ }^{40}$ which Turkey has refused to pay. ${ }^{41}$

The applicant initiated ex parte proceedings at the Famagusta District Court, ${ }^{42}$ requesting that the court issues a garnishee order nisi, enforceable against the European Commission ('the garnishee'), joining Turkey as a respondent. The claim concerned the funds purportedly earmarked by the Commission to be used as financial aid towards pre-accession measures taken by Turkey. A sum of $€ 624,900,000$ is targeted towards promoting human rights and the rule of law in Turkey. ${ }^{43}$

In a brief judgment, the District Court issued a garnishee order nisi, freezing relevant assets, on the condition that the immunity of the Commission would be waived before the CJEU. If the Commission's immunity were to be waived, then the case could be returned before the District Court to obtain a garnishee order absolute. This judgment demonstrates that the ECtHR judgment addressed to Turkey and the res judicata it generates have been recognised and can be enforced by the Cypriot national court. However, the judge's reasoning explaining the legal mechanics underpinning this recognition is brief.

\footnotetext{
38 ECtHR 23 March 1995, Case No. 15318/89 Loizidou (Preliminary Objections) v Turkey, para. 62.

${ }^{39}$ ECtHR 22 September 2009, Case No. 29092/95 Ramon v Turkey.

${ }^{40}$ ECtHR 26 October 2010, Case No. 29092/95 Ramon v Turkey (Just Satisfaction), operative para. 2.

${ }^{41}$ Interim Resolution CM/ResDH (2014) 185 (n. 4).

42 Cypriot national court.

43 Ramon (national judgment) (n. 28), p. 4.
} 
One should first consider the recognition of ECtHR judgments through the lens of domestic law. It may be that, as for precedents arising out of the case-law of the ECtHR, the recognition of the ECtHR award in domestic legal order largely depends on national law. In Ramon (national judgment), the court stated that Article 169 of the Constitution of Cyprus formed part of the legal basis for the application. ${ }^{44}$ Article 169(3) states that:

'Treaties, conventions and agreements concluded in accordance
with the foregoing provisions of this Article shall have $/ \ldots /$
superior force to any municipal law on condition that such
treaties, conventions and agreements are applied by the other
party thereto.'

The Cypriot judge considered that this Article, which gives the ECHR a superlegislative ranking within the domestic legal order, is not limited to the provisions of ECHR but also confers legal force upon orders made by the ECtHR. ${ }^{45}$ This empowers the national court to recognise the operative part of an ECtHR judgment.

The use of Article 169(3) as a legal basis is significant because there are equivalent provisions in constitutions of several Contracting Parties. Such examples include Article 55 of the French Constitution, Article 5(4) of the Bulgarian Constitution and Article 93 of the Dutch Basic Law. Notably, Article 93 of the Dutch Basic Law also refers to 'resolutions by international organisations' which could, by analogy, be applied to the judgments of the ECtHR, especially when considered in conjunction with the commitment in Article 90 to 'promote the development of the international legal order'. Ramon (national judgment) indicates that these equivalent constitutional provisions could plausibly be interpreted to allow national courts to recognise the resjudicata arising from an ECtHR judgment.

\footnotetext{
${ }^{44}$ Ibid, pp. 2-3.

${ }^{45}$ This is not the case in all national legal systems (Nollkaemper, 2013: p. 532).
} 
The above establishes that there is a plausible constitutional vehicle in several Contracting Parties that could allow national courts to recognise the operative part of ECtHR judgments. One should also consider, from an international law perspective, whether the ECHR regime contains elements that could promote the transposition of res judicata into the domestic legal order.

It is argued that the quasi-direct effect conferred on precedents emanating from ECtHR judgments should be extended to the res judicata element of judgments. As established above, the ECtHR considers that precedent set in a judgment should be directly effective within the municipal legal order of the respondent State if that precedent is precise and complete. ${ }^{46}$ As argued, subsequent State practice suggests that this approach may have been extended so that a precedent is given a sort of direct effect in the legal orders of many Contracting Parties, even if the judgment is not addressed to them.

There is no reason, in principle, that would prevent employing an analogous approach regarding the operative part of ECtHR judgments. The operative part gives rise to the respondent State's obligation to take particular measures to remedy the violation in question. This obligation, especially the just satisfaction element, should be sufficiently complete and precise. Hence, it is argued that the respondent State's obligation to pay just satisfaction should be directly effective and, therefore, self-executing within the domestic legal order of the Contracting Parties whose constitutions have been receptive to the direct effect of precedent. The prospect of extending legal effects of the ECtHR judgments beyond the respondent State has been recognised by commentators (Villiger, 2014: p. 34). This would mean that the national court of a Contracting Party could recognise the obligation of another respondent State to pay the applicant within its own domestic legal order. Arguably, this is also in line with the overarching obligation imposed upon Contracting Parties under Article 1 ECHR to 'secure to everyone within their jurisdiction the [Convention] rights and freedoms $/ \ldots /$ '.

${ }^{46}$ Vermeire (n. 31). 
Two conclusions should be drawn from the above analysis. Primarily, there is fertile ground on the domestic constitutional plane of many Contracting Parties for allowing national courts to recognise res judicata generated from ECtHR judgments addressing other States. Secondly, it has been argued that the quasi-direct effect, which appears to have been accorded to precedent, should also be extended to res judicata. Importantly, in the form of Ramon (national judgment), we already have a national court judgment that recognises an order made by the ECtHR against another Contracting Party. Transposing ECtHR judgments into national law in this way is necessary as it is the national court that issues the garnishee order concerning the claim, which is the focus of this paper. More generally, this transposition is the first step towards mobilising the national legal order to ensure the effective execution of judgments of the ECtHR through alternative means.

\subsubsection{Is there an issue regarding sovereign immunity?}

A notable feature of Ramon (national judgment) is the absence of any consideration of the sovereign immunity enjoyed by Turkey before the Cypriot courts. This should be considered of the court's own volition (Fox and Webb, 2015: p. 12) and may be raised upon returning the case to the District Court to obtain the garnishee order absolute. Two issues will be examined: (i) Turkey's immunity from suit before the Cypriot court and (ii) Turkey's immunity from execution.

In relation to (i), it is argued that Turkey should not be able to invoke its immunity from suit for two reasons. Primarily, Turkey is subject to the jurisdiction of the ECtHR by virtue of Article 34 ECHR and Article 46 ECHR. Given Turkey's consent to the jurisdiction of the original court (namely the ECtHR), the Cypriot court should be entitled to exercise its jurisdiction under common law over Turkey in order to recognise the judgment of the ECtHR. This appears to be the position regarding foreign national judgments under Cypriot private international law (Christoforou, 2019: pp. 18-19), which could be extended to ECtHR judgments. 
Secondly, Article 6 ECHR may require that the Cypriot court does not bar the applicant's claim on the basis of sovereign immunity. In Al-Adsani v $U K,{ }^{47}$ the ECtHR held that restrictions on the applicant's access to court on the basis of sovereign immunity should not impair the very essence of the applicant's Article 6 rights. Furthermore, it required that the interference with the applicant's right of access to court should be proportionate to the legitimate aim pursued. ${ }^{48}$ Commentators have suggested that if the immunity leaves the applicant with no alternative means of obtaining redress, such immunity may be disproportionate, meaning that the forum court would violate Article 6 ECHR (McGregor, 2013: pp. 133-136). In Ramon, the applicant has fulfilled the obligation to exhaust all domestic remedies (Article 35(1) ECHR) and has obtained a judgment before the ECtHR finding a violation, without having had this violation remedied. Given that these proceedings are the applicant's last resort, it is argued that a procedural bar on his claim would constitute a violation of his Article 6 rights by the Cypriot court. Hence, the obligations of the Cypriot court to accord immunity would conflict with its obligation to uphold Convention rights.

Regarding Turkey's immunity from execution, it is argued that this is not relevant to the present case. States are generally immune from execution measures against their property (Fox, 2014: p. 358). However, the assets targeted by the order are currently owned by the Commission. There appears to be no precedent on whether State immunity from execution should apply to property that is expected to be transferred to the relevant State. In these circumstances, it is argued that Turkey's immunity should not bite. It is clear that the Commission's immunity should be overcome to obtain the relevant sums. It would be illogical if the same property would be subject both to the immunity of the Commission and to the immunity of the State which expects to receive this property. Therefore, it is argued that the lack of consideration of Turkey's immunity from execution is not detrimental to the claim in Ramon.

In any event, the CJEU has no jurisdiction to review the national court's garnishee order on its merits (Lenaerts, Maselis and Gutman 2015: para. 14.06). Since the Cypriot court had made the conditional garnishee order, it is necessary to examine the potential waiver of the Commission's immunity.

\footnotetext{
${ }^{47}$ ECtHR 21 November 2001, Case No. 35763/97, Al-Adsani v UK, para. 53.

${ }^{48}$ Ibid, paras.S 53-55.
} 


\subsection{Overcoming the hurdle of the European Commission's Immunity}

\subsubsection{The Law pertaining to the Commission's immunity}

The second element of the claim concerns the waiver of the Commission's immunity pursuant to Article 1 Protocol No. 7 TEU. The immunity in question is automatic (Lenaerts, Maselis and Gutman, 2015: para.14.06). A waiver of this immunity would allow the garnishee order to be served on the Commission, thereby making it subject to the jurisdiction of the national court that has issued the order. Hence, had the Commission's immunity been waived in Ramon, it would appear before the Famagusta District Court to contest the garnishee order to be made absolute.

Generally, if no objection is raised by the Commission, the CJEU does not need to consider the application for authorisation (Lenaerts, Maselis and Gutman, 2015: para.14.05). Alternatively, the CJEU may order the waiver of the Commission's immunity. The test to determine whether the CJEU will order the waiver of the Commission's immunity is laid down in the case of Antippas v Commission. In that case, the CJEU states that it will consider whether:

'[The garnishee order is] likely, in view of the effects which [it
has] under the applicable national law, to interfere with the
proper functioning and independence of the [European
Union]. ${ }^{\prime 49}$

If relevant measures do interfere in such a way, the CJEU will decline the applicant's request to waive the immunity of the Commission.

The test above is stringent. Successful applications to authorise the service of garnishee order are rare (Lenaerts, Maselis and Gutman, 2015: para.14.07). Nevertheless, in Générale de Banque $v$ Commission, ${ }^{50}$ the CJEU waived the Commission's immunity so that the applicant could execute the garnishee order visà-vis rent owed by the Commission to the Belgian government. The order regarding

\footnotetext{
${ }^{49}$ Case C-1/02 SA, Antippas v Commission, ECLI:EU:C:2003:187, para. 14.

${ }^{50}$ Case 1/88 SA, Générale de Banque v Commission, ECLI:EU:C:1989:142.
} 
those funds was held to not 'interfere with the proper functioning and independence' of the EU.

\subsubsection{Ramon and analogous cases}

The test to determine whether the Commission's immunity should be waived is strict, particularly when the order pertains to funds allocated to financing the EU's common policies. ${ }^{51}$ The order in Ramon was targeted towards funds that finance such policies. The existing case law did not favour the applicant. Nonetheless, it was argued that Ramon may be distinguished from the existing case law on Article 1 of Protocol No. 7 TEU on the basis that the order in Ramon is rooted in a judgment of the ECtHR, which awarded the relevant sum as redress for a human rights violation. As far as the author is aware, no analogous cases had come before the CJEU.

This paper will examine arguments raised by the applicant regarding how the human rights dimension of the garnishee order could affect the application to waive the Commission's immunity before the CJEU. In Ramon (CJEU), the court declined to order the waiver of the Commission's immunity. Nevertheless, this judgment does not bar similar claims in the future.

\subsubsection{The Human Rights Dimension of the garnishee order}

The logical first question is whether the CJEU should have taken into account the human rights nature of the garnishee order at all. It was argued that the CJEU should do so for two reasons. Primarily, the national judgment made explicit reference to the human rights nature of the order. ${ }^{52}$ The transposition of the ECtHR judgment into national law does not alter the human rights basis of the claim.

Secondly, to ignore the human rights element of the case and to treat it as a simple debt order would be unduly formalistic. The case-law of the CJEU suggests that it is not averse to taking into account the initial judgment which the national court of a Member State is enforcing by issuing the garnishee order. ${ }^{53} \mathrm{By}$ analogy, the CJEU

\footnotetext{
51 Ibid, para. 13.

52 Ramon (national judgment) (n. 28), pp. 10-11.

53 Antippas (n. 49), para. 3, even though the CJEU did not consider the substance of the claim before the DRC courts.
} 
should be able to take note of the fact that the garnishee order in Ramon is enforcing an ECtHR judgment. Failing to attach any weight to this dimension of the order would arguably be inconsistent with Article 2 TEU, ${ }^{54}$ read in conjunction with Article 6(3) TEU, which provides that ECHR rights constitute general principles of EU law. In any event, the relevance of the human rights element of the case was accepted by the Commission in its defence.

\subsubsection{The Applicant's Submissions in Ramon}

One should now examine how the human rights nature of the claim would affect the determination of the CJEU regarding the Commission's immunity. The applicant argued that the human rights dimension of the claim was relevant because: (i) it meant that the garnishee order would not interfere with the proper functioning and independence of the EU and (ii) failure to waive the Commission's immunity would interfere with the applicant's right to effective judicial protection, as guaranteed by the general principles of EU law.

In Antippas, the CJEU considered that the application would interfere with the proper functioning of the EU. Consequently, it rejected the application to waive the Commission's immunity, justifying its decision as follows:

'To authorise a garnishee order in this case would result in appropriating funds expressly intended by the Community for the development cooperation policy, to special interests which are foreign to that policy.' 55

It was argued that the human rights nature of the judgment underpinning the garnishee order in Ramon meant that the Commission's policy would not be subject to interests that are 'foreign' to that policy. In fact, the garnishee order in question promoted policy objectives pursued by the Commission.

\footnotetext{
${ }^{54}$ Consolidated version of the Treaty on European Union [2008] C115/13.

55 Antippas (n. 49), para. 19 (emphasis added).
} 
As mentioned, the garnishee order concerned funds purportedly allocated to finance Turkey's pre-accession measures. These funds, inter alia, aimed to promote and protect human rights. ${ }^{56}$ Furthermore, the preamble of the Regulation establishing an instrument for pre-accession assistance explicitly states that it was adopted under Article 212(2) TFEU. ${ }^{57}$ Measures taken pursuant to this provision 'shall be carried out within the framework of the principles and objectives of [the Union's] external action' (Article 212(1) TFEU). These principles and objectives, which govern the whole of Title V TFEU on external policy, are set out in Articles 3(5) and 21 TEU. In particular, Article 21(1) TEU provides that:

'The Union's action on the international scene shall be guided by the principles which have inspired its own creation ... and which it seeks to advance in the wider world: democracy, the rule of law, the universality and indivisibility of human rights and fundamental freedoms ... and respect for the principles of the United Nations Charter and international law.'

Moreover, Article 21(2)(b) TEU requires that the Union pursues common policies in order to 'consolidate and support democracy, the rule of law, human rights and the principles of international law'.

It is evident that in formulating external policy, the EU institutions are bound to promote the protection of human rights (Craig and De Búrca, 2015: pp. 392-393). In defining the term 'human rights', note should be taken of Article 6 TEU, which sets out the three sources of fundamental rights recognised in the EU legal order. These are: (i) the Charter of Fundamental Rights (hereinafter: CFR or the Charter) ${ }^{58}$ (Article 6(1) TEU); (ii) the ECHR rights, which are protected as general principles of EU law (Article 6(3) TEU) and (iii) other general principles of EU law (Article 6(3) TEU). The ECHR has long been considered to have a special status when formulating general principles of EU law. ${ }^{59}$ Therefore, it appears that 'human rights' referred to in Article 21 TFEU must include the rights guaranteed under the ECHR, transposed into the EU legal order as general principles.

\footnotetext{
${ }^{56}$ Regulation (EU) No. 231/2014 of the European Parliament and of the Council of 11 March 2014 establishing an Instrument for Pre-accession Assistance (IPA II), Art. 1(a)(ii).

${ }^{57}$ Consolidated version of the Treaty on the Functioning of the European Union [2012] OJ C326/47.

${ }^{58}$ Charter of Fundamental Rights of the European Union [2016] OJ C202/389.

${ }^{59}$ Case 4/73 Nold KG v Commission [1974] ECR 491, para. 13.
} 
In deciding whether to waive the Commission's immunity, it was argued that the CJEU should take into account the fact that the order made in Ramon was aligned with the Commission's obligations under the Treaties and is, therefore, not 'foreign' to the policy objectives of the Union. The EU requires that States looking to join the Union must implement the judgments of the ECtHR. ${ }^{60}$ Hence, the execution of the monetary aspect of an ECtHR judgment through the garnishee order would manifestly not 'interfere with the proper functioning and independence of the EU'.

The applicant's second argument in favour of waiving the Commission's immunity was that if the Commission failed to do so, this would violate the applicant's right to effective judicial protection, guaranteed under general principles of EU law. The general principle of effective judicial protection is reaffirmed in Article 47 CFR. ${ }^{61}$ The right enshrined in the CFR only applies in relation to 'rights / .../ guaranteed by the law of the Union'. Hence, the provision does not secure effective judicial protection in relation to the applicant's right under Article 1 Protocol 1 ECHR vis-àvis Turkey, as Turkey is not bound by the Charter. Therefore, the right is not guaranteed by EU law.

Despite the above, the underlying general principle of effective judicial protection exists independently of the Charter provision. The latter is a manifestation of the former. This general principle could be a self-standing source of rights (Tridimas, 2014: p. 380). Furthermore, the principle of effective judicial protection may have a different scope of application than the right codified in the CFR. Hoffmann and Mihaescu have shown that the underlying general principle of good administration has a different personal, institutional and material scope from the equivalent right codified in Article 41 CFR (Hoffmann and Mihaescu, 2013: p. 101). By analogy, the principle of effective judicial protection need not be limited to rights emanating from EU law. Hence, the operative question becomes: Could the general principle of effective judicial protection require that such protection is afforded in relation to rights guaranteed under the ECHR?

\footnotetext{
${ }^{60} \mathrm{CM} / \mathrm{AS}$ (2007) Rec1764 'Implementation of judgments of the European Court of Human Rights, Parliamentary Assembly Recommendation 1764' (30 March 2007), para. 7.

${ }^{61}$ Joined Cases C-402/05 P and C-415/05 P Yassin Abdullah Kadi and Al Barakaat International Foundation v Council of the European Union and Commission [2008] ECR I-6351, para. 335.
} 
It was argued that the general principle of effective judicial protection should require that such protection be extended to ECHR rights for three reasons. Primarily, the ECHR rights constitute general principles of EU law. While, pending accession to the ECHR, EU institutions are not bound by these rights, the Convention rights have a 'special significance' in the development of general principles of EU law. ${ }^{62}$ This would suggest that the general principle of effective judicial protection could cover Convention rights.

Secondly, the CJEU suggested that the ECHR may be treated as an independent source of rights within the EU legal order. This is illustrated in Festersen. ${ }^{63}$ In this case, the CJEU reviewed the compatibility of Danish law requiring the owner of agricultural land to reside on that land with the free movement of capital (Article 63 TFEU). Inter alia, the CJEU considered that it should take into account the fact that the relevant law interfered with the right to choose one's place of residence freely, as guaranteed by Article 2(1) Protocol No. 4 ECHR. Significantly, this right is not included in the Charter but appears to have been transposed into the EU legal order.

Thirdly, the interplay between fundamental rights, as guaranteed by the ECHR and the $\mathrm{EU}$, has led to the creation of a 'common constitutional space' within the EU with a view to securing the protection for fundamental rights (Lenaerts and Guttiérez-Fons, 2014: para. 55.03). Within this space, the combined effect of Articles 52(3) and 53 CFR indicates that the CFR cannot be interpreted as providing a lower level of protection to fundamental rights than that accorded under the ECHR (Lenaerts and Guttiérez-Fons, 2014: para. 55.59-55.60). Hence, allowing Article 47 CFR to undermine the general principle of effective judicial protection in relation to the Convention rights would appear to contradict this commitment and would be inconsistent with the tenor of Article 2 TEU.

If the general principle of effective judicial protection extends to the applicant's Convention rights, this right would require that the remedy given in response to the violation of Article 1 Protocol 1 should be effective so as not to allow a final binding decision to remain inoperative. This is in accordance with jurisprudence emanating

\footnotetext{
${ }^{62}$ Case C-274/99 P Connolly v Commission [2001] ECR I-1611, para. 37.

${ }^{63}$ Case C-370/05 [2007] ECR I-1129, para. 35.
} 
from Article 6 and $13 \mathrm{ECHR},{ }^{64}$ in which the principle is also enshrined. ${ }^{65}$ Given that the ECtHR judgment has not been executed by Turkey and the apparent inability of the CoM to compel such execution, it is likely that if the Commission refuses to waive its immunity, the applicant will be left without effective redress. This would constitute an interference with his right to effective judicial protection.

The applicant submitted that the interference with the principle of effective judicial protection should be taken into account by the CJEU so as to subject the non-waiver to a proportionality assessment. The interference pursues a legitimate aim in safeguarding the Commission's policy autonomy. However, when fundamental rights are at stake, including the right to effective judicial protection, the policy autonomy of EU institutions appears to be subordinated to such rights. For example, in Maximillian Schrems, ${ }^{66}$ the CJEU annulled a decision made by the Commission allowing the transfer of personal data to a non-EU State. The reason was, in part, that the applicant's right to effective judicial protection would not be respected in the receiving jurisdiction. Hence, the decision was outside the scope of Directive 95/46, ${ }^{67}$ interpreted in light of Article 47 CFR. It was argued that given the rights at stake in the present case, the scope allowed for the Commission's policy autonomy should be subject to a strict proportionality review. Given that the garnishee order is consistent with the Commission's Treaty obligations and policy objectives, it was argued that the interference with the applicant's right to effective judicial protection by refusing to waive the immunity would be disproportionate.

\subsubsection{The Commission's Defence and Ramon (CJEU)}

In its defence, the Commission argued that the amount targeted by the applicant and the order issued by the Famagusta District Court in Ramon (national judgment) had been cut from the budget approved on the basis of Article 310 TFEU. According to the Commission, the relevant funds had been reallocated to finance projects in other States in the Western Balkans. Consequently, Turkey had no claim for any specific or liquidated sums against the EU on which the applicant could anchor the garnishee claim. Secondly, the Commission submitted that the waiver of the Commission's

\footnotetext{
${ }^{64}$ ECtHR 19 March 1997, Case No. 18357/91 Hornsby v Greece, para. 40.

${ }^{65}$ Case 222/84, Marguerite Johnston v Chief Constable of the Royal Ulster Constabulary, [1986] ECR 1651, para. 18.

${ }^{66}$ Case C-362/14, Maximillian Schrems v Data Protection Commissioner, EU:C:2015:650, paras. 95-98.

${ }^{67}$ European Parliament and Council Directive 95/46/EC of 24 October 1995 on the protection of individuals with regard to the processing of personal data and on the free movement of such data, OJ L281/31.
} 
immunity would 'significantly interfere with the proper functioning and independence of the [European Union]'. Finally, it argued that the applicant's ability to bring an application pursuant to Article 1 Protocol No. 7 TEU safeguarded his rights under Article 47 Charter without disputing the relevance of the right to this case. ${ }^{68}$

In its judgment, the CJEU rejected the applicant's claim and accepted the Commission's first argument regarding the lack of Turkey's liquidated claim against the Commission. ${ }^{69}$ Significantly, the Court refrained from taking any position on the human rights issues raised by the applicant. The Court's judgment constitutes a departure from the previous case law, which clearly states that it is within the exclusive jurisdiction of the domestic court to determine whether the conditions for the issuing of a garnishee order have been met, including the question of the garnishee's indebtedness to the judgment debtor. ${ }^{70}$ The CJEU has not adequately explained its reasons for departing from this established line of cases.

It is argued that the objections raised by the Commission should have been put before the Famagusta District Court as the appropriate forum, following the waiver of the Commission's immunity and the return of the case before the domestic court, so that it could determine whether the garnishee order nisi should be converted into the garnishee order absolute. This would have been in line with the established case law.

Furthermore, the application was dismissed on the basis that Turkey did not have any liquidated claim against the Commission on which to anchor the garnishee order. The relevance of the human rights dimension of the case was not disputed by the Commission and not discussed by the CJEU in its judgment. In light of this, it is argued that the judgment should not bar any future attempts to use this avenue as a method of executing the judgments of the ECtHR. Indeed, if the appropriate debts had been targeted, the CJEU would have to examine the arguments raised by the applicants (as outlined above).

\footnotetext{
${ }^{68}$ Ramon (CJEU) (n. 29), paras. 19-23.

${ }^{69}$ Ibid, paras. 30.

${ }^{70}$ Antippas (n. 49), para. 13.
} 


\section{$4 \quad$ Conclusion}

The current institutional framework supervising the execution of the ECtHR judgments relies heavily on the cooperation of States. The democratic backsliding occurring in some Contracting Parties, such as Turkey, Russia and Azerbaijan, and their resistance towards discharging their secondary obligations has cast doubt over the effectiveness of this model. It has been argued that the current framework places undue reliance on political pressure as a tool to compel States to execute the judgments of the ECtHR. In response to this deficiency, the mechanisms of legal accountability should be used to supplement the current system. Absent reform, the ECtHR cannot be viewed as a coercive legal mechanism. Therefore, it has been suggested that national courts and adjacent legal institutions could fulfil this function.

Having suggested that national courts could play a role in promoting the execution of the ECtHR's judgments, this study has considered one way to achieve this end. The proposed claim involves the applicant seeking a garnishee order in order to collect just satisfaction owed to him by a debtor of the respondent State. In particular, this paper focuses on cases where the garnishee is an EU institution. The above analysis indicates that the proposed claim has two elements. Primarily, the applicant must ensure that the award of just satisfaction, made by the ECtHR, is recognised within the domestic legal order of the forum State. It has been argued that such recognition is plausible, as illustrated in Ramon (national judgment). Secondly, the applicant must overcome the hurdle of the EU institution's immunity. It has been argued that the human rights dimension of the claim should weigh in favour of waiving this immunity. Admittedly, the proposed claim is not necessarily a panacea that would ensure the payment of just satisfaction in all cases. However, it could compel the payment of just satisfaction in the Xenides-Aresti group ${ }^{71}$ and other analogous cases.

Significantly, this paper calls for a novel approach to the execution of ECtHR judgments. Little to no research has been carried out on how the national courts of non-respondent Contracting Parties could contribute to the execution of the ECtHR's judgments. This study constitutes the first step in the exploration of these

\footnotetext{
${ }^{71}$ Interim Resolution CM/ResDH (2014) 185 (n. 4).
} 
alternative avenues, which would utilise legal orders adjacent to the ECHR in order to ensure the execution of the ECtHR's judgments.

There have been calls to create a 'united front across Europe' (Observatoire International des Avocats, 2018: p. 23) to ensure the continued effectiveness of the ECtHR as the guardian of human rights in Europe. While such rhetorical devices have often been employed, it appears that no one has, as of yet, explored the methods through which such a front could be created. This study presents one potential approach towards this end. More importantly, this paper is a call for human rights advocates everywhere to think of creative ways through which they can aid the ECHR regime where it has proven to be ineffective. It is up to us to pick up the mantle. Alternatively, we risk allowing States to cherry-pick human rights obligations they comply with, undermining the legitimacy of the ECHR regime.

\section{References}

Anagnostou and Mungiu-Pippidi (2014) Domestic Implementation of Human Rights Judgments in Europe: Legal Infrastructure and Government Effectiveness Matter, European Journal of International Law, 25(1), p. 205.

CCBE (2019) CCBE Proposals for reform of the ECHR machinery, Council of Bars and Law Societies of Europe.

Christoforou (2019) Cyprus. In Enforcement of Foreign Judgments edited by Garb and Lew. Kluwer Law International.

$<$ https://kluwerlawonline.com/ManualChapter/Enforcement+of+Foreign+Judgements/E FJ20190030>.

Committee of Ministers (2020) Supervision of the Execution of Judgments and Decisions of the European Court of Human Rights: 14th Annual Report of the Committee of Ministers (Strasbourg: Council of Europe).

Council of Europe (2004) Explanatory Report to Protocol No. 14 to the Convention for the Protection of Human Rights and Fundamental Freedoms, amending the control system of the Convention (Strasbourg: Council of Europe).

Craig and De Búrca (2015) EU Law, 6th edition (Oxford: Oxford University Press).

Dalhuisen (2017) In Turkey, defending human rights is a crime. Politico, 19 July $<$ https://www.politico.eu/article/amnesty-international-in-turkey-defending-human-rightsis-a-crime $>$.

De Londras and Dzehtsiarou (2017) Mission Impossible? Addressing Non-implementation through infringement proceedings in the European Court of Human Rights, International and Comparative Law Quarterly, 66, p. 467.

De Wet (2008) The Reception Process in the Netherlands and Belgium. In A Europe of Rights: The Impact of the ECHR on National Legal Systems edited by Keller and Stone Sweet (Oxford: Oxford University Press).

Fikfak (2018) Changing State Behaviour: Damages before the European Court of Human Rights, European Journal of International Law, 29(4), p. 1091. 
Fox (2014) International Law and Restraints on the Exercise of Jurisdiction by National Courts of States. In International Law edited by Evans, 4th edition (Oxford: Oxford University Press).

Fox and Webb (2015) The Law of State Immunity, $3^{\text {rd }}$ edition (Oxford: Oxford University Press).

Glas (2017) The Theory, Potential and Practice of Procedural Dialogue in the European Convention on Human Rights Intersentia.

Hafner-Burton (2018) Sticks and Stones: Naming and Shaming the Human Rights Enforcement Problem, International Organisation, 62(4), p. 689.

Helfer and Slaughter (1997) Toward a Theory of Effective Supranational Adjudication, Yale Law Journal, 107, p. 273.

Hoffmann and Mihaescu (2013) The relation between the Charter's fundamental rights and the unwritten general principles of EU law: good administration as the test case, European Constitutional Law Review, 9(1), p. 73.

Observatoire International des Avocats (2018) (In)Effective Remedies from Strasbourg $<$ https://eldh.eu/wp-content/uploads/2018/06/DAV_Conference_Report__Turkey_and_the_ECtHR_-_March_2018.pdf $>$.

Keller and Marti (2016) Reconceptualising Implementation: The Judicialisation of the Execution of the European Court of Human Rights' Judgments, European Journal of International Law, 26(4), p. 829 .

Lambert-Abdelgawad (2008) The Execution of Judgments of the European Court of Human Rights, $2^{\text {nd }}$ edition (Strasbourg: Council of Europe).

Lenaerts and Guttiérez-Fons (2014) The Charter in the EU Constitutional Edifice. In The EU Charter of Fundamental Rights edited by Peers, Hervey, Kenner and Ward (Oxford: Hart).

Lenaerts, Maselis and Gutman (2015) EU Procedural Law (Oxford: Oxford University Press).

Martinico (2012) Is the European Convention going to be 'Supreme'? A Comparative-Constitutional Overview of ECHR and EU Law before National Courts, European Journal of International Law, 23(2), p. 401.

McGregor (2013) State Immunity and Human Rights: Is there a Future after Germany v Italy?, Journal of International Criminal Justice, 11, p. 125.

Nollkaemper (2013) Conversations among Courts: Domestic and International Adjudicators. In The Oxford Handbook of International Adjudication edited by Romano, Alter and Shany (Oxford: Oxford University Press).

Paraskeva (2018) European Court of Human Rights: From Declaratory Judgments to Indications of Specific Measures, European Human Rights Law Review, 1, p. 46.

Polakiewicz (2002) The Execution of Judgments of the European Court of Human Rights. In Fundamental Rights in Europe edited by Blackburn and Polakiewicz (Oxford: Oxford University Press).

Polakiewicz (2017) Between 'Res Judicata' and 'Orientierungswirkung' - ECHR Judgments Before National Courts. Brno: Council of Europe <https://www.coe.int/en/web/dlapil/-/betweenres-judicata-and-orientierungswirkung-\#_edn4>.

Ress (2005) The Effect of Decisions and Judgments of the European Court of Human Rights in the Domestic Legal Order, Texas International Law Journal, 40(3), p. 359.

Tridimas (2014) Fundamental Rights, General Principles of EU Law and the Charter, Cambridge Yearbook of European Legal Studies, 16, p. 369.

Villiger (2014) Binding Effect and Declaratory Nature of the Judgments of the European Court of Human Rights: An Overview. In Judgments of the European Court of Human Rights - Effects and Implementation edited by Seibert-Fohr and Villiger (Routledge). 